\title{
Progesterone vaginal ring: Beneficial role in supporting breastfeeding
}

Population Council

Follow this and additional works at: https://knowledgecommons.popcouncil.org/departments_sbsr-rh

Part of the Demography, Population, and Ecology Commons, Family, Life Course, and Society Commons, International Public Health Commons, and the Maternal and Child Health Commons How does access to this work benefit you? Let us know!

\section{Recommended Citation}

"Progesterone vaginal ring: Beneficial role in supporting breastfeeding," Project brief. New York: Population Council, 2016. 


\section{WHAT IS THE ISSUE?}

There is a revived focus on breastfeeding and its benefits, especially because of the lack of significant progress in global rates of breastfeeding since the launch of the Innocenti Declaration in 1990 and the Baby Friendly Hospital Initiative in 1991 (Rollins et al. 2016). Women in high-income countries tend to breastfeed for shorter durations than those in low- and middle-income countries. Furthermore, even in low- and middle-income countries, less than two-fifths of infants under six months of age are breastfed exclusively, with a trend toward reductions in continued breastfeeding among poorer women (Victora et al. 2016).

There is ample evidence for the potential of breastfeeding to further lower infant and child mortality and morbidity while simultaneously improving women's health. Breastfed children tend to be protected from infections, have fewer dental malocclusions, and have higher intelligence than those who are not breastfed (Victora et al. 2016). It is estimated that improved breastfeeding practices could reduce more than 800,000 deaths among children under age five and 20,000 deaths among women with breast cancer annually (Victora et al. 2016). Thus breastfeeding is a health behavior that impacts both mother and child and has the potential to contribute to the newly formulated Sustainable Development Goal 3, which focuses on good health and the well-being of individuals. It is within this context that a call for concerted action to protect, promote, and support breastfeeding has been issued (Rollins et al. 2016).

Breastfeeding has also been identified as a high-impact intervention to achieve the Global Strategy for Women's, Children's and Adolescents' Health (2016-2030), which was launched alongside the Sustainable Development Goals as a roadmap for ending preventable deaths in a generation. Breastfeeding is important to child survival in all settings and helps ensure that children can thrive and reach their full cognitive and developmental potential throughout their lives (www.who.int/maternal_child_adolescent/news_events/news/2016/ exclusive-breastfeeding/en/).

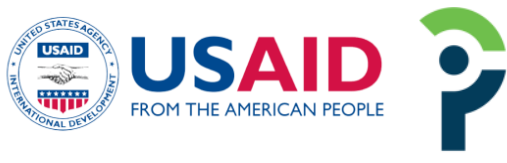

POPULATION COUNCIL

Ideas. Evidence. Impact. 


\section{BENEFITS OF BREASTFEEDING}

Breastfeeding is a low-cost and readily available intervention with enormous benefits for both mother and baby. Breast milk provides infants with all the nutrients they need for healthy development as well as protection against diarrhea and pneumonia, the two primary causes of child mortality worldwide (Horta and Victora 2013).

Evidence also suggests that breastfeeding contributes to improved outcomes in later life; adolescents and adults who were breastfed as babies are less likely to be overweight/obese or have type 2 diabetes, and perform better in intelligence tests.

Mothers also receive both short- and long-term benefits. In the short term, exclusive breastfeeding can protect against pregnancy ( $98 \%$ protection in the first six months after birth) and postpartum depression, and in the longer term can reduce risks of breast and ovarian cancers, as well as type 2 diabetes.

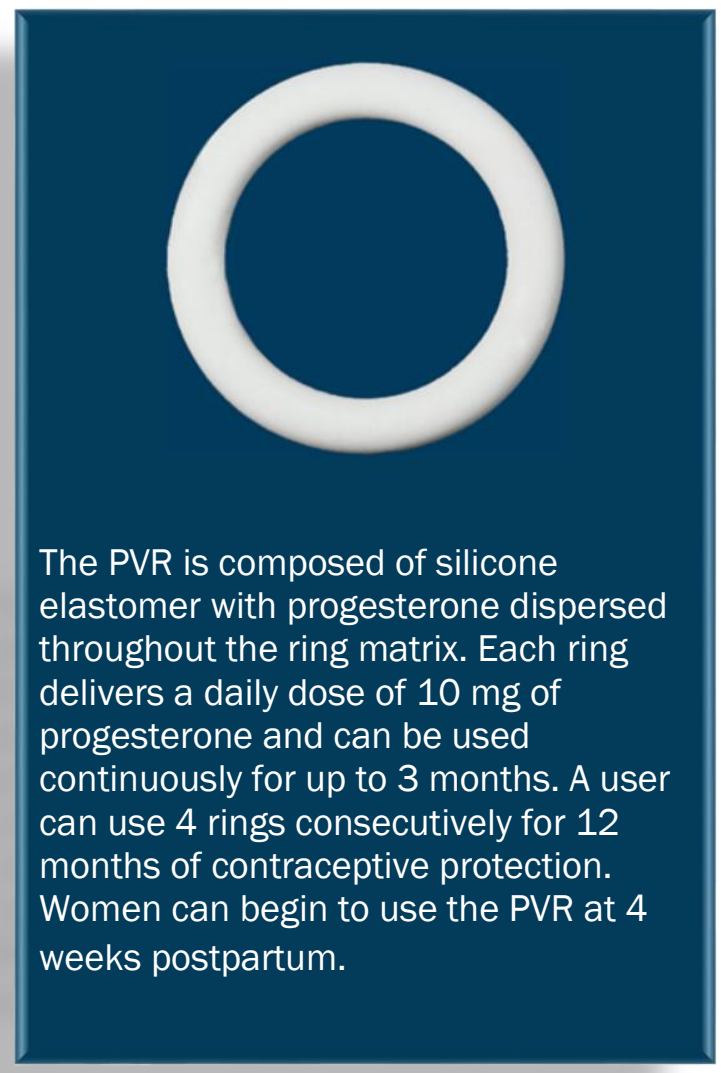

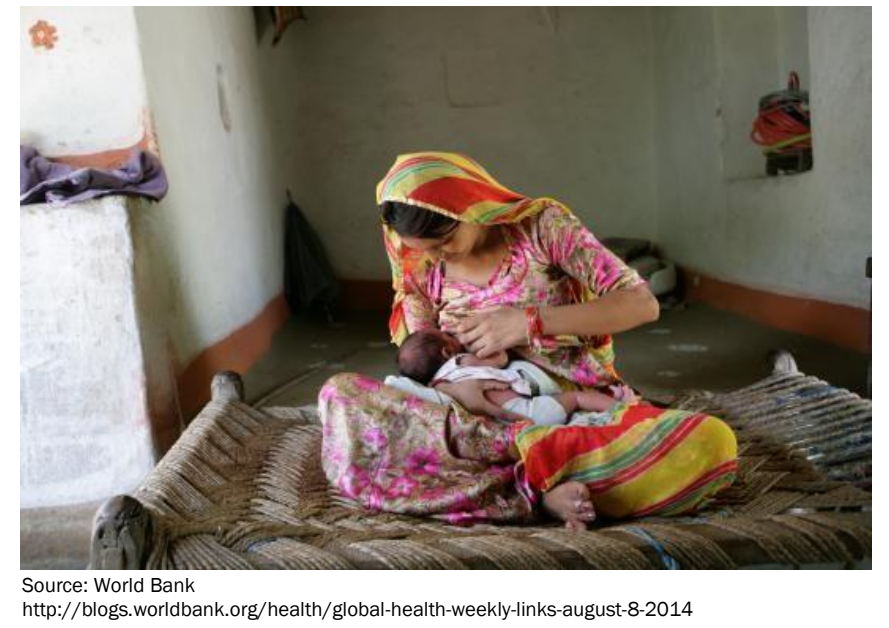

\section{PROGESTERONE VAGINAL RING}

The Progesterone Vaginal Ring (PVR) is a new contraceptive designed for use by breastfeeding women to extend the period of lactational amenorrhea and promote birth spacing (RamaRao et al. 2013). The natural progesterone contained in the ring does not interfere with breastfeeding, and the progesterone is inactivated quickly when ingested orally; the infant is not exposed to the hormone if a small amount is secreted into breast milk (Massai et al. 1999; Massai et al. 2000).

The effectiveness of the PVR depends on the user breastfeeding her child at least four times a day, with fewer feeds reducing effectiveness. Hence, in populations where breastfeeding is an accepted behavior but with potential for reductions in how often it is practiced, the PVR provides an additional rationale to promote and support sustained or increased nursing. The PVR is included in the Fifth Edition of the WHO Medical Criteria for Contraceptive Use (WHO 2015).

The PVR is an ideal tool to achieve two different but connected health outcomes. On the one hand, it supports (and even promotes) breastfeeding so that infants and children are well nourished, protected from a host of illnesses, and benefit from nursing that is uninterrupted by a pregnancy. On the other hand, the PVR enhances contraceptive protection for the mother so that she has ample time to recover from the previous pregnancy and delivery, while devoting her attention to the newly delivered baby. 


\section{BENEFITS OF USING CONTRACEPTION}

WHO recommends an interval of 24 months or more after a live birth before becoming pregnant, in order to reduce poor health outcomes for mother and baby (WHO 2007). However, considerable proportions of pregnancies occur within 24 months of a live birth; data from 22 Demographic and Health Surveys (DHS) indicate that over $50 \%$ of non-first pregnancies occurred within 24 months of the previous birth (Moore et al. 2015). Given the potential for postpartum family planning to meet women's contraceptive needs and contribute to healthier babies and mothers, WHO and its partners have issued new guidance for postpartum family planning (WHO 2013). The guidance covers important topics such as: raising awareness of family planning needs among postpartum women, reducing missed opportunities across the continuum of care, organizing health services to include contraceptive counseling, maximizing the availability of communitybased care, and expanding the range of family planning options and services.

The lactational amenorrhea method, or LAM, is recommended for up to six months postpartum for women who do not wish to use modern contraception. LAM is effective under three conditions. First, LAM requires that the new mother exclusively breastfeed every four hours during the day and every six hours at night and desist from feeding water, formula, or other milk. Second, the method works for up to the first six months postpartum, after which the new mother will have to utilize other methods to prevent pregnancy. Third, LAM is only effective provided the woman has not started menstruating since giving birth. These stringent conditions limit the proportion of women who are able to use LAM effectively (Sitruk-Ware et al. 2016). The PVR is an option for those women who wish to breastfeed but are not able to use LAM and are seeking an alternate contraceptive.

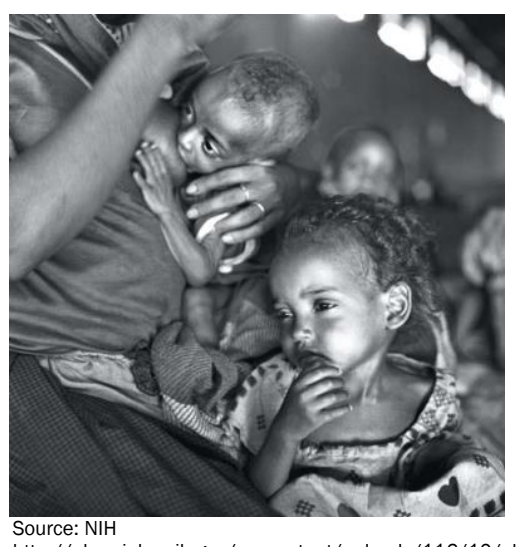

http://ehp.niehs.nih.gov/wp-content/uploads/116/10/ehp.116-a426.pdf

\section{LINKS BETWEEN BREASTFEEDING, NUTRITION, AND POSTPARTUM CONTRACEPTION}

DHS data reveal that malnutrition is a global concern that requires immediate attention, especially in subSaharan Africa and South Asia. Malnutrition arises when an individual lacks macronutrients, such as carbohydrates and proteins, or micronutrients (vitamins and minerals), or both. Infants and children under the age of five years are especially susceptible to malnutrition, leading to stunting, wasting, and underweight conditions. Addressing malnutrition is essential for reducing childhood mortality and morbidity.

Nutrition from breast milk, especially during the first two years of a child's life, is a naturally potent means of combating the various outcomes of malnutrition and of increasing immediate and long-term immunity.

Exclusive breastfeeding during the first four months is especially crucial to provide nutrients to the infant that other supplements are unable to adequately provide in order to protect the child from infections, anemia, and other outcomes of malnutrition, while bonding the mother and child (World Food Programme 2005). In 41 states throughout sub-Saharan Africa and India, exclusive breastfeeding ranges between $96 \%$ and $98 \%$ for the first two to four months of an infant's life. Further, continued breastfeeding in addition to supplemental food and milk continue between 18 and 25 months according to DHS data. Continued breastfeeding also provides benefits for the mother, specifically by reducing stress, increasing bonding with the child, and providing a constant source of nutrition in emergency situations (UNICEF). A malnourished woman may still breastfeed and provide the necessary nutrients to her child, although additional support from food and supplements would increase her ability to lactate (UNICEF).

Since breastfeeding is vital for the health of both the mother and baby through increased bonding and continued nutrition, preventing pregnancy in the first year postpartum is important. Less than $1 \%$ of women currently use LAM, with no more than $6 \%$ having ever used the method in select countries. Given the frequency with which women have to breastfeed exclusively immediately after giving birth for up to six months, after which LAM no longer guarantees contraceptive protection, the need for contraceptive use is high. 


\section{KEY FACTS FROM SELECTED COUNTRIES}

\begin{tabular}{|c|c|c|c|}
\hline Country & $\begin{array}{l}\text { Prevalence } \\
\text { of } \\
\text { Malnutrition }\end{array}$ & $\begin{array}{c}\text { Current } \\
\text { Breastfeeding } \\
\text { Practices }\end{array}$ & $\begin{array}{c}\text { Need for } \\
\text { Contraceptive } \\
\text { Use }\end{array}$ \\
\hline \multirow{3}{*}{$\begin{array}{c}\text { Sub- } \\
\text { Saharan } \\
\text { Africa }^{1}\end{array}$} & $\begin{array}{l}35 \% \\
\text { children } \\
\text { stunted }\end{array}$ & $\begin{array}{l}97 \% \text { children } \\
\text { currently } \\
\text { breastfed }\end{array}$ & $\begin{array}{l}0.5 \% \text { of all } \\
\text { women are } \\
\text { currently using } \\
\text { LAM }\end{array}$ \\
\hline & $\begin{array}{l}8 \% \text { children } \\
\text { wasted }\end{array}$ & $\begin{array}{l}\text { Mean duration } \\
\text { of exclusive } \\
\text { breastfeeding - } \\
3 \text { mon }\end{array}$ & $\begin{array}{l}6 \% \text { of all } \\
\text { women have } \\
\text { ever used LAM }\end{array}$ \\
\hline & $\begin{array}{l}18 \% \\
\text { children } \\
\text { underweight }\end{array}$ & $\begin{array}{l}\text { Mean duration } \\
\text { of any } \\
\text { breastfeeding - } \\
20 \text { mon }\end{array}$ & $\begin{array}{l}40.7 \% \text { of births } \\
\text { whose mothers } \\
\text { are postpartum } \\
\text { insusceptible }\end{array}$ \\
\hline \multirow{3}{*}{ Kenya } & $\begin{array}{l}33.2 \% \\
\text { children } \\
\text { stunted }\end{array}$ & $\begin{array}{l}99.5 \% \text { children } \\
\text { currently } \\
\text { breastfed }\end{array}$ & $\begin{array}{l}0 \% \text { of all } \\
\text { women are } \\
\text { currently using } \\
\text { LAM }\end{array}$ \\
\hline & $\begin{array}{l}2.8 \% \\
\text { children } \\
\text { wasted }\end{array}$ & $\begin{array}{l}\text { Mean duration } \\
\text { of exclusive } \\
\text { breastfeeding - } \\
4.3 \text { mon }\end{array}$ & $\begin{array}{l}1.9 \% \text { of all } \\
\text { women have } \\
\text { ever used LAM }\end{array}$ \\
\hline & $\begin{array}{l}10.3 \% \\
\text { children } \\
\text { underweight }\end{array}$ & $\begin{array}{l}\text { Mean duration } \\
\text { of any } \\
\text { breastfeeding - } \\
21.3 \text { mon }\end{array}$ & $\begin{array}{l}31.3 \% \text { of births } \\
\text { whose mothers } \\
\text { are postpartum } \\
\text { insusceptible }\end{array}$ \\
\hline \multirow{3}{*}{ Nigeria } & $\begin{array}{l}37.9 \% \\
\text { children } \\
\text { stunted }\end{array}$ & $\begin{array}{l}95.9 \% \text { children } \\
\text { currently } \\
\text { breastfed }\end{array}$ & $\begin{array}{l}1 \% \text { of all } \\
\text { women are } \\
\text { currently using } \\
\text { LAM }\end{array}$ \\
\hline & $\begin{array}{l}2.2 \% \\
\text { children } \\
\text { wasted }\end{array}$ & $\begin{array}{l}\text { Mean duration } \\
\text { of exclusive } \\
\text { breastfeeding - } \\
1.8 \text { mon }\end{array}$ & $\begin{array}{l}\text { No data } \\
\text { available }\end{array}$ \\
\hline & $\begin{array}{l}9.3 \% \\
\text { children } \\
\text { underweight }\end{array}$ & $\begin{array}{l}\text { Mean duration } \\
\text { of any } \\
\text { breastfeeding - } \\
18.3 \text { mon }\end{array}$ & $\begin{array}{l}39.9 \% \text { of births } \\
\text { whose mothers } \\
\text { are postpartum } \\
\text { insusceptible }\end{array}$ \\
\hline \multirow{3}{*}{ Senegal } & $\begin{array}{l}37.9 \% \\
\text { children } \\
\text { stunted }\end{array}$ & $\begin{array}{l}99.1 \% \text { children } \\
\text { currently } \\
\text { breastfed }\end{array}$ & $\begin{array}{l}0.1 \% \text { of all } \\
\text { women are } \\
\text { currently using } \\
\text { LAM }\end{array}$ \\
\hline & $\begin{array}{l}9.3 \% \\
\text { children } \\
\text { wasted }\end{array}$ & $\begin{array}{l}\text { Mean duration } \\
\text { of exclusive } \\
\text { breastfeeding - } \\
2.7 \text { mon }\end{array}$ & $\begin{array}{l}\text { No data } \\
\text { available }\end{array}$ \\
\hline & $\begin{array}{l}16.4 \% \\
\text { children } \\
\text { underweight }\end{array}$ & $\begin{array}{l}\text { Mean duration } \\
\text { of any } \\
\text { breastfeeding - } \\
20.3 \text { mon }\end{array}$ & $\begin{array}{l}36.7 \% \text { of births } \\
\text { whose mothers } \\
\text { are postpartum } \\
\text { insusceptible }\end{array}$ \\
\hline \multirow{3}{*}{ India } & $\begin{array}{l}48 \% \\
\text { children } \\
\text { stunted }\end{array}$ & $\begin{array}{l}98 \% \text { children } \\
\text { currently } \\
\text { breastfed }\end{array}$ & $\begin{array}{l}\text { No data } \\
\text { available }\end{array}$ \\
\hline & $\begin{array}{l}20 \% \\
\text { children } \\
\text { wasted }\end{array}$ & $\begin{array}{l}\text { Mean duration } \\
\text { of exclusive } \\
\text { breastfeeding - } \\
4 \text { mon }\end{array}$ & $\begin{array}{l}\text { No data } \\
\text { available }\end{array}$ \\
\hline & $\begin{array}{l}43 \% \\
\text { children } \\
\text { underweight }\end{array}$ & $\begin{array}{l}\text { Mean duration } \\
\text { of any } \\
\text { breastfeeding - } \\
25 \text { mon }\end{array}$ & $\begin{array}{l}27 \% \text { of births } \\
\text { whose mothers } \\
\text { are postpartum } \\
\text { insusceptible }\end{array}$ \\
\hline
\end{tabular}

${ }^{1}$ Average of 40 countries listed in the Appendix from DHS data.

\section{CALL TO ACTION: ROLE OF STAKEHOLDERS}

Breastfeeding is a right to health for women and their children and concerted action by public and private actors is critical. Women need support to initiate and continue breastfeeding their babies. Currently, women do not breastfeed for a multitude of reasons ranging from lack of knowledge about the latest scientific evidence, work pressures, inconvenience, limited provider guidance, and lack of familial or community support. Successful breastfeeding requires protection and support from multiple actors in the health arena, and the following lays out actions that they can take:

Policy and program managers can emphasize the importance of breastfeeding as a key public health approach that can prevent multiple diseases and improve the health of mothers and babies (McFadden et al. 2016).

- Decision-makers can situate breastfeeding within larger health and developmental agendas.

- Decision-makers can ensure that breastfeeding is better integrated across service programs, in particular family planning, so that breastfeeding is not isolated within infant and child feeding and nutrition programs.

- A well-integrated breastfeeding program will incorporate the array of tools and technologies that are available to support and promote breastfeeding; key examples include LAM and the PVR.

Health regulators can monitor and stop false advertising from companies that promote breastmilk substitutes as being superior to breast milk.

- Regulators should monitor and implement existing laws that penalize breast-milk substitute companies for false or deceptive advertising thereby signaling explicit support for breastfeeding initiatives.

- Regulators can introduce appropriate and good-quality technologies that promote and support breastfeeding, such as breast pumps, relevant medications that increase the production of breast milk, and contraceptives such as the Progesterone Vaginal Ring developed for nursing women. 
Providers can support breastfeeding women at the various points of service contact they have with women and their babies, whether at health facilities or through community outreach.

- Providers, irrespective of their training and professional responsibilities, should support and promote breastfeeding. For example, obstetricians and gynecologists should counsel women during antenatal and postnatal visits regarding the benefits of breastfeeding. Frontline workers such as nurses, midwives, and community-based health workers should teach and support women on the art of optimal breastfeeding.

- Providers can counsel a breastfeeding woman about contraceptive options such as LAM, the PVR, and other progestin-based methods should she desire to avoid or delay the next pregnancy.

Health advocates can argue for regulations and guidelines that expand maternity benefits, including those at the workplace.

- Advocates can fight for private places for women to breastfeed or express milk in both public and private spaces and thereby support women's decisions to nurse their babies.

- Advocates can create the agenda that supports workplace entitlements that provide women with the time (maternity leave), space (nursing rooms), and flexibility to manage work and childrearing responsibilities.

- Advocates can disseminate key messages on breastfeeding and family planning that support the health of mothers and babies. They can partner with technical-support agencies in distilling and translating science-based messages for actions.

Families and community members at large can play an influential role in supporting a woman's decision and right to breastfeed (Lawn and Kerber 2006).

- Family members including spouses can support a woman's decision to nurse and to use contraception. They can provide her relief from household chores, give her time and space to nurse, and offer practical advice and support.

- Communities can allocate a positive value to breastfeeding and address any stigma-such as not being a modern behavior-that is attached to breastfeeding.
- Communities can create mother-to-mother support groups, breastfeeding support groups, or mothers' clubs that can be avenues of support to breastfeeding women.

Suggested citation: Population Council. 2016. "Progesterone Vaginal Ring: Beneficial Role in Supporting Breastfeeding." New York: Population Council.

This publication is made possible by the generous support of the American people through the United States Agency for International Development (USAID). The contents are the responsibility of the Population Council and do not necessarily reflect the views of USAID or the United States Government.

\section{REFERENCES}

Horta, Bernardo L. and Cesar G. Victora, 2013. “Short-term effects of breastfeeding: A systematic review on the benefits of breastfeeding on diarrhoea and pneumonia mortality." WHO: Geneva.

Lawn, Joy and Kate Kerber (eds.). 2006. Opportunities for Africa's Newborns: Practical Data, Policy and Programmatic Support for Newborn Care in Africa. Cape Town, South Africa: PMNCH

Massai, R., Soledad Diaz, Ted Jackanicz, and Horatio B. Croxatto. 2000. “Vaginal rings for contraception in lactating women," Steroids, Vol. 65(10-11): 703-707.

Massai R., P. Miranda, P. Valdes, P. Lavin, A. Zepeda, M.E. Casado, et al. 1999. "Preregistration study on the safety and contraceptive efficacy of a progesterone-releasing vaginal ring in Chilean nursing women," Contraception, Vol. 60(1): 9-14.

McFadden, Alison, Frances Mason, Jean Baker, France Begin, Fiona Dykes, et al. 2016. "Spotlight on infant formula: Coordinated global action needed," Lancet, Vol. 387(10017): 413-415.

Moore, Zhuzhi, Anne Pfitzer, Rehana Gubin, Elaine Charurat, Leah Elliott, and Trevor Croft. 2015. “Missed opportunities for family planning: An analysis of pregnancy risk and contraceptive method use among postpartum women in 21 low and middle-income countries," Contraception, Vol. 92(1): 31-39.

RamaRao, Saumya, Heather Clark, Ruth Merkatz, Heather Sussman, and Régine Sitruk-Ware. 2013. "Progesterone vaginal ring: Introducing a contraceptive to meet the needs of breastfeeding women," Contraception, Vol. 88(5): 591-598.

Rollins, Nigel C., Nita Bhandari, Nemat Hajeebhoy, Susan Horton, Chessa K. Lutter, et al. 2016. "Why invest, and what it will take to improve breastfeeding practices?" Lancet, Vol. 387(10017): 491-504.

Sitruk-Ware, Régine, Saumya RamaRao, Ruth Merkatz, and John W. Townsend. 2016. "Risk of pregnancy in breastfeeding mothers: Role of the Progesterone vaginal ring in birthspacing," European Medical Journal of Reproductive Health (accepted).

UNICEF. "Breastfeeding and Malnutrition in Mothers." Common Concerns about Breastfeeding.

Victora, Cesar G., Rajiv Bahl, Aluisio J.D. Barros, Giovanny V.A. França, Susan Horton, et al. 2016. "Breastfeeding in the 21st century: Epidemiology, mechanisms, and lifelong effect," Lancet, Vol. 387(10017): 475-490.

WHO Medical Eligibility Criteria for Contraceptive Use. Fifth edition, 2015. http://apps.who.int/iris/bitstream/10665/181468/1/9789241549158_eng. pdf?ua $=1$

World Food Programme. 2005. "Defining and measuring malnutrition." $A$ Manual: Measuring and Interpreting Malnutrition and Mortality. Micronutrient Initiative. Pages 15-32.

World Health Organization (WHO). 2007. Report of a WHO Technical Consultation on Birth Spacing. Geneva, Switzerland, 13-15 June 2005. WHO: Geneva.

World Health Organization (WHO). 2013. Programming strategies for postpartum family planning. WHO: Geneva. 
APPENDIX: DHS STATISTICS

\begin{tabular}{|c|c|c|c|c|c|c|c|c|c|c|}
\hline \multirow[b]{2}{*}{ Country } & \multirow[b]{2}{*}{ Survey } & \multicolumn{3}{|c|}{$\begin{array}{l}\text { Anthropometric Measures- } \\
\text { Outcomes of Malnourishment }\end{array}$} & \multicolumn{3}{|c|}{ Current Breastfeeding Practices } & \multicolumn{3}{|c|}{ Need for Contraceptive Use } \\
\hline & & $\begin{array}{l}\text { Children } \\
\text { stunted } \\
(\%)\end{array}$ & $\begin{array}{c}\text { Children } \\
\text { wasted } \\
(\%)\end{array}$ & $\begin{array}{c}\text { Children } \\
\text { under- } \\
\text { weight (\%) }\end{array}$ & $\begin{array}{c}\text { Children } \\
\text { currently } \\
\text { breastfeeding } \\
(\%)\end{array}$ & $\begin{array}{c}\text { Mean } \\
\text { duration of } \\
\text { exclusive } \\
\text { breastfeeding }\end{array}$ & $\begin{array}{c}\text { Mean } \\
\text { duration of } \\
\text { any } \\
\text { breastfeeding } \\
\text { (months) }\end{array}$ & $\begin{array}{l}\text { Current } \\
\text { use of LAM } \\
\text { (\% of all } \\
\text { women) }\end{array}$ & $\begin{array}{c}\text { Ever use } \\
\text { of LAM } \\
\text { (\% of all } \\
\text { women) }\end{array}$ & $\begin{array}{c}\text { Postpartum } \\
\text { insusceptible } \\
\text { (\% by } \\
\text { months } \\
\text { since giving } \\
\text { birth) }\end{array}$ \\
\hline Benin & $\begin{array}{l}2011-12 \\
\text { DHS }\end{array}$ & 44.6 & 16 & 21.3 & 89.8 & 3.3 & 19.4 & 0.4 & 3.9 & 43.1 \\
\hline Botswana & $1988 \mathrm{DHS}$ & 34.6 & 15.5 & 25.7 & 96 & 2.7 & 17.8 & 0.1 & 1.1 & 43.2 \\
\hline Burkina Faso & 2010 DHS & 57.7 & 5.8 & 28.8 & 99.1 & 2.2 & 23.9 & 0 & 6.9 & 45.9 \\
\hline Burundi & 2010 DHS & 32.5 & 5.6 & 14.6 & 98.7 & 4.8 & 25 & 0.2 & 6.9 & 40.9 \\
\hline Cameroon & 2011 DHS & 39.1 & 9.3 & 22.2 & 97.5 & 1.9 & 17 & 0.9 & 0.3 & 38.2 \\
\hline $\begin{array}{l}\text { Central } \\
\text { African } \\
\text { Republic }\end{array}$ & $\begin{array}{l}\text { 1994-95 } \\
\text { DHS }\end{array}$ & 44.6 & 15.9 & 32.6 & 99.8 & 0.9 & 21.2 & 0.5 & 14.6 & 48.8 \\
\hline Chad & $\begin{array}{l}\text { 1996-97 } \\
\text { DHS }\end{array}$ & 30.1 & 11.1 & 15.3 & 99.5 & 0.8 & 21.7 & 0.4 & 0.4 & 44.9 \\
\hline Comoros & 2012 DHS & 24.4 & 5.9 & 11.6 & 94.4 & 1.5 & 18.2 & 1.4 & 6 & 24.6 \\
\hline $\begin{array}{l}\text { Congo } \\
\text { (Brazzaville) }\end{array}$ & $\begin{array}{l}2011-12 \\
\text { DHS }\end{array}$ & 42.7 & 7.9 & 22.6 & 94.8 & 1.9 & 15.9 & 0 & 2.8 & 33.4 \\
\hline $\begin{array}{l}\text { Congo } \\
\text { Democratic } \\
\text { Republic }\end{array}$ & $\begin{array}{l}\text { 2013-14 } \\
\text { DHS }\end{array}$ & 29.8 & 7.5 & 14.9 & 98.4 & 3.6 & 21.8 & 0 & 3.3 & 41.1 \\
\hline Cote d'Ivoire & $\begin{array}{l}2011-12 \\
\text { DHS }\end{array}$ & 42.9 & 14.9 & 33.8 & 96.4 & 1.4 & 18.9 & 0.1 & 9 & 38 \\
\hline Eritrea & 2002 DHS & 44.4 & 9.7 & 28.7 & 100 & 4.3 & 22.3 & 1.1 & 5.1 & 49.7 \\
\hline Ethiopia & 2011 DHS & 16.5 & 3.3 & 6 & 98.5 & 4.2 & 25.3 & 0.1 & 2.7 & 49 \\
\hline Gabon & 2012 DHS & 24.5 & 11.5 & 16.2 & 88 & 1.1 & 11.6 & 0.1 & 23.9 & 28.8 \\
\hline Gambia & 2013 DHS & 18.8 & 4.7 & 11 & 99.2 & 3.6 & 20.7 & 0 & 5 & 45.6 \\
\hline Ghana & 2014 DHS & 31.2 & 9.6 & 18 & 99.2 & 3.9 & 21.2 & 0.8 & 3.6 & 36.2 \\
\hline Guinea & 2012 DHS & 26 & 4 & 11 & 98.2 & 2.2 & 22.8 & 0.3 & 8.3 & 63.2 \\
\hline Kenya & 2014 DHS & 33.2 & 2.8 & 10.3 & 99.5 & 4.3 & 21.3 & 0 & 1.9 & 31.3 \\
\hline Lesotho & 2014 DHS & 31.6 & 6 & 15 & 93.6 & 4.5 & 16.6 & 0.1 & 3.1 & 40.4 \\
\hline Liberia & 2013 DHS & 50.1 & & & 98.4 & 4 & 19.6 & 0.1 & 17.1 & 40.4 \\
\hline Madagascar & $\begin{array}{l}2008-09 \\
\text { DHS }\end{array}$ & 47.1 & 4 & 12.8 & 99.6 & 3.7 & 22.5 & 3.5 & 1.7 & 34.2 \\
\hline Malawi & 2010 DHS & 38.3 & 12.7 & 25.5 & 99.4 & 4.7 & 23 & 0.3 & 0.3 & 39.8 \\
\hline Mali & $\begin{array}{l}2012-13 \\
\text { DHS }\end{array}$ & 38.9 & 14.5 & 27.8 & 95.7 & 3.3 & 22.6 & 0.1 & 16 & 40.4 \\
\hline Mauritania & $\begin{array}{l}2000-01 \\
\text { DHS }\end{array}$ & 42.6 & 5.9 & 14.9 & 98.8 & 2.2 & 19.7 & 0.4 & 3.8 & 37.3 \\
\hline Mozambique & 2011 DHS & 23.7 & 6.2 & 13.3 & 97.5 & 3.5 & 20.4 & 0.1 & & 49.5 \\
\hline Namibia & 2013 DHS & 43.9 & 18 & 36.4 & 92 & 3.5 & 14.8 & 0.7 & & 41.7 \\
\hline Niger & 2012 DHS & 36.8 & 18 & 28.7 & 98.2 & 2.1 & 20.4 & 0.8 & & 42.6 \\
\hline Nigeria & 2013 DHS & 37.9 & 2.2 & 9.3 & 95.9 & 1.8 & 18.2 & 1 & & 39.9 \\
\hline Rwanda & $\begin{array}{l}2014-15 \\
\text { DHS }\end{array}$ & 29.3 & 10.5 & 13.1 & 99.5 & 6.1 & 27.2 & 0.1 & & 40.2 \\
\hline $\begin{array}{l}\text { Sao Tome } \\
\text { and Principe }\end{array}$ & $\begin{array}{l}2008-09 \\
\text { DHS }\end{array}$ & 18.7 & 5.9 & 12.6 & 100 & 4 & 18 & 0.5 & & 32 \\
\hline Senegal & 2014 DHS & 37.9 & 9.3 & 16.4 & 99.1 & 2.7 & 20.3 & 0.1 & & 36.7 \\
\hline Sierra Leone & 2013 DHS & 28.9 & 2.5 & 5.4 & 96.4 & 2.9 & 19 & & & 52.7 \\
\hline South Africa & 1998 DHS & 42 & 4.8 & 15.8 & 83.4 & 1.2 & 15.6 & & & 43.6 \\
\hline Sudan & $\begin{array}{l}1989-90 \\
\text { DHS }\end{array}$ & 27.5 & 6.5 & 16 & 98.3 & 2.4 & 19.4 & & & 41.7 \\
\hline Swaziland & $\begin{array}{l}2006-07 \\
\text { DHS }\end{array}$ & 33.4 & 4.7 & 13.8 & 89.9 & 2.6 & 15.6 & & & 42.4 \\
\hline Tanzania & 2010 DHS & 40.1 & 6.0 & 14.8 & 98.3 & 3.8 & 20.4 & & & 37.3 \\
\hline Togo & $\begin{array}{l}2013-14 \\
\text { DHS }\end{array}$ & 32.0 & 3.0 & 9.7 & 98.4 & 4 & 22.5 & & & 39.1 \\
\hline Uganda & 2011 DHS & & & & 97.5 & 4.5 & 19.3 & & & 33.9 \\
\hline Zambia & $\begin{array}{l}2013-14 \\
\text { DHS }\end{array}$ & & & & 98.7 & 4.9 & 20.1 & & & 36.1 \\
\hline Zimbabwe & $\begin{array}{l}2010-11 \\
\text { DHS }\end{array}$ & & & & 96.7 & 2.8 & 17.5 & & & 40.2 \\
\hline
\end{tabular}

